\title{
ERRATUM
}

\section{Erratum to: Stoichiometry among bioactive trace metals in seawater on the Bering Sea shelf}

\author{
Abigail Parcasio Cid · Syouhei Urushihara • \\ Tomoharu Minami $\cdot$ Kazuhiro Norisuye · \\ Yoshiki Sohrin
}

Published online: 22 March 2012

(C) The Oceanographic Society of Japan and Springer 2012

Erratum to: J Oceanogr (2011) 67:747-764
DOI 10.1007/s10872-011-0070-z

The original article was published with errors which are corrected below:

1. In the abstract, the sentence "The stoichiometry of D-M in the Bering Sea shelf showed enrichment of Co and $\mathrm{Pb}$ and depletion of $\mathrm{Ni}, \mathrm{Cu}, \mathrm{Zn}$, and $\mathrm{Cd}$ compared with that in the North Pacific."

should read as

"The stoichiometry of D-M in the Bering Sea shelf showed enrichment of trace metals, especially $\mathrm{Al}, \mathrm{Mn}, \mathrm{Fe}$, $\mathrm{Co}$ and $\mathrm{Cu}$ compared with that in the North Pacific."

2. In Fig. 10, there were mistakes in the calculation for the Pacific deep water. The original figure should be replaced by the following figure.

The online version of the original article can be found under doi: $10.1007 / \mathrm{s} 10872-011-0070-\mathrm{z}$.

A. P. Cid · S. Urushihara - T. Minami - K. Norisuye

Y. Sohrin $(\bowtie)$

Institute for Chemical Research, Kyoto University,

Uji, Kyoto 611-0011, Japan

e-mail: sohrin@scl.kyoto-u.ac.jp
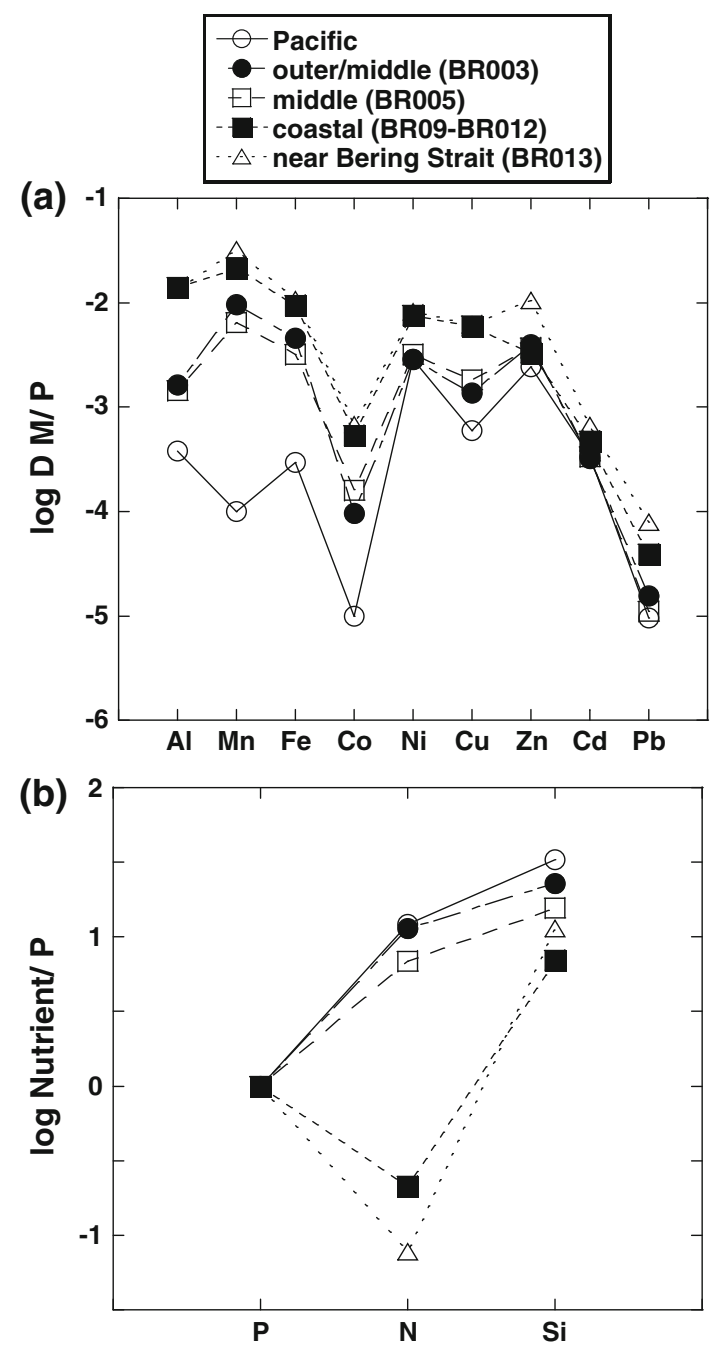
3. In Fig. 11, there was a mistake in the scale of $y$-axis. The original figure should be replaced by the following figure.

\begin{tabular}{|cccc|}
$-\mathrm{Mn}$ & $-\mathrm{Co}$ & $-\mathrm{Cu}$ & $-\mathrm{Cd}$ \\
$\exists \mathrm{Fe}$ & $-\triangle-\mathrm{Ni}$ & $\diamond \mathrm{Zn}$ & $-\xi-\mathrm{Pb}$ \\
\hline
\end{tabular}

Station BR0-

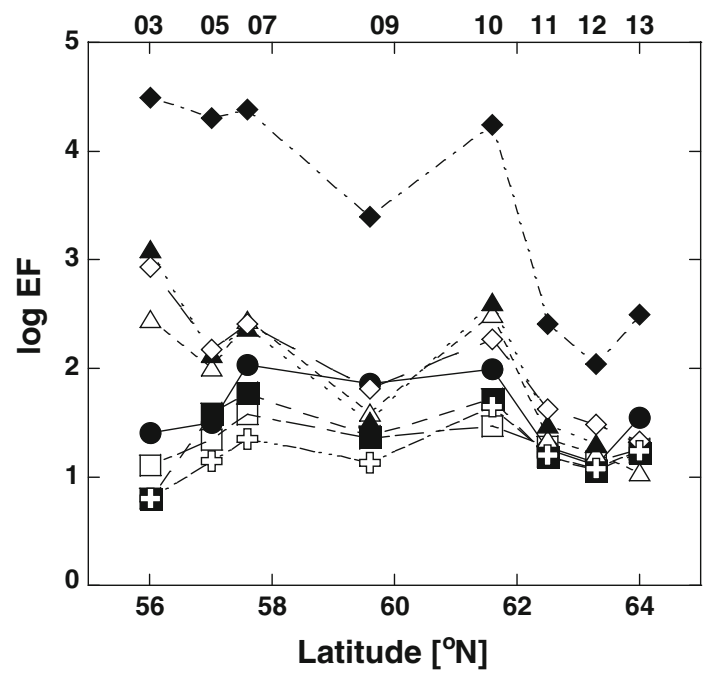

4. In the last paragraph of Sect. 4.4, the sentences starting from "The Si/P ratio is lowest in" to "and $\mathrm{Cd}$ on the Bering Sea shelf."

should read as

"The Si/P ratio is highest in the North Pacific and outer shelf domain and lowest in the coastal domain. The D-M/P ratios show different variations from $\mathrm{N} / \mathrm{P}$ and $\mathrm{Si} / \mathrm{P}$. It is apparent that the Bering Shelf is enriched with trace metals, especially $\mathrm{Al}, \mathrm{Mn}, \mathrm{Fe}, \mathrm{Co}$ and $\mathrm{Cu}$ compared with that in the North Pacific. The major reasons should be as follows: (1) the North Pacific deep water is depleted in $\mathrm{Al}$, $\mathrm{Mn}, \mathrm{Fe}$ and $\mathrm{Co}$ by scavenging; (2) there is preferential supply of trace metals over P on the Bering Sea shelf."

5. In "Conclusions", the sentence "Relative to phosphate, the Bering Sea shelf was enriched with D-Co and $\mathrm{D}-\mathrm{Pb}$ and depleted in D-Ni, D-Cu, D-Zn, and D-Cd compared with the North Pacific."

should read as

"Relative to phosphate, the Bering Sea shelf was enriched with trace metals, especially $\mathrm{Al}, \mathrm{Mn}, \mathrm{Fe}, \mathrm{Co}$ and $\mathrm{Cu}$ compared with the North Pacific." 